\title{
BRITISH ASSOCIATION INQUIRY INTO THE METRIC SYSTEM
}

$\mathrm{T}$ the young scientist making contact with industry or commerce fresh from school or university it comes as rather a shock to find that his general 'scientific' usage of the c.G.S. system has such small acceptance in the outside 'practical' world. True, he has used 'Winchester quarts' to hold his standard solutions made up in grams per litre, he has stirred with fractional h.p. motors and dabbled in foot-poundals and lb./sq. in. But he has learned to think in metric units and centigrade degrees. $\mathrm{He}$ knows that engineers seem to be able to exist with other units, and he respects their attempts to decimalize the rather antique units that he finds them using. $\mathrm{He}$ will probably be surprised to learn that Great Britain narrowly missed adopting the metric system of weights and measures almost one hundred years ago by a handful of votes in Parliament. Since then, the question has been the subject of heated discussion on many occasions. The most recent general investigation appears in Part 1 of the Hodgson Report produced in May 1951 by the Committee set up under Sir Edward Hodgson by the Board of Trade. This made the following recommendations.

That the Imperial system should eventually be abolished in favour of the metric, and that the change should be preceded by : (a) discussion with industry and commerce to determine the period of transition; (b) agreement with the Commonwealth and the United States for a simultaneous change on their parts ; (c) a lengthy process of preparing the general public for the change; $(d)$ decimalization of the coinage; (e) preparation of schemes for the compulsory change-over, trade by trade, during the period of transition, with provision for compensation wherever necessary.

The Hodgson Committee did not attempt to assess the cost to the country of a general adoption of the metric system, and from time to time one sees statements quoting very large figures indeed as the 'cost' of the change-over. Even in the short period since 1951 the international situation and the climate of opinion have been changing, and we have seen the increasing emphasis on pan-Europeanism and we have recently seen the official adoption of the metric system by India.

One of the main objects of the inquiry now instituted under the auspices of the British Association for the Advancement of Science is to make a statistical estimate of the short-term cost and the long-term profit to Great Britain of a change-over to the metric system, rather than to assess current opinion on the matter. In short, to find out whether we cannot afford to make the change or whether we cannot afford not to make the change. To this end it is proposed to approach a cross-section of British industry with the co-operation of the Federation of British Industries and the various trade associations. It is hoped that a factual appraisal will help to form opinion and that these basic facts will be of assistance to those who have to make the decision. Certainly, without facts the subject will remain largely a means of arousing passion.

There is one by no means unimportant aspect of the question on which action could well be taken irrespective of a general change-over in industry and commerce. This is the question of school education. It seems that in any event the people of Britain will have to live with two systems side by side for many years and that at present there is too little attention given to proficiency in the metric system among non-scientific students; and together with this goes the question of rationalization of the existing Imperial system, some elements of which could surely be eliminated forthwith.

The British Association Committee which is to study this question is under the chairmanship of Sir Hugh Beaver and is composed of Dr. A. H. Hughes, deputy chairman (assistant managing director of Arthur Guinness, Son and Co., Ltd.), Dr. R. Beeching (director of Imperial Chemical Industries, Ltd.), Mr. M. G. Bennett (general treasurer, British Association), Prof. C. F. Carter (professor of applied economics, Queen's University of Belfast), Mr. Hugh Conway (joint managing director, Short Brothers and Harland, Ltd.), Mr. A. C. Hartley (consulting engineer), Mr. F.S. Walker (chairman of Lever Brothers, Port Sunlight, Ltd.) and Mr. C. P. Jones (Rolls-Royce, Ltd.).

\section{NEWS and VIEWS}

\section{Royal Society of Edinburgh : David Anderson-Berry Prize}

THE Royal Society of Edinburgh has made two awards of the David Anderson-Berry Prize for 1958 : to Mr. W. M. Court Brown, director, Medical Research Council Group for Research on the General Effects of Radiation, Western General Hospital, Edinburgh, and Dr. Richard Doll, Medical Research Council Statistical Research Unit, London School of Hygiene and Tropical Medicine, London, for their work on the incidence of leukæmia after exposure to radiation; and to Dr. C. E. Ford, Medical Research Council Radiobiological Research Unit, Atomic Energy Research Establishment, Harwell, for his work on the survival of transplanted marrow cells after exposure of the recipient to radiation, so making an important extension of the field of radiotherapy. Each recipient will receive a cash award together with a David Anderson-Berry Silver-Gilt Medal.

\section{Soddy Commemoration Plaques}

AT a dinner to scientists and politicians given by Lord Grantchester in the House of Lords on May 16, three plaques were shown which are to be set up in commemoration of the late Prof. Frederick Soddy, first B itish Nobel laureate in chemistry. Mr. T. E. Rodd, science master of Eastbourne College, was presented with one in bronze and white enamel. This is to be installed in one of the new laboratories of the College, which is to be called the Frederick Soddy 